\title{
Belgrade Adolescent Personality Inventory: Bridging the Gap between Personality Assessment in Children and Adults ${ }^{1}$
}

\author{
Džamonja Ignjatović Tamara ${ }^{2}$ \\ University of Belgrade, Faculty of Political Sciences
}

\section{Milanović Marko ${ }^{3}$}

Belgrade

\section{Dukanac Vesna \\ Institute of Mental Health, Belgrade}

\begin{abstract}
Personality inventories for assessment and study temperament and character of adolescents, an age critical for the finalisation of both normal and pathological mental development, have not been specifically developed. In this paper, we introduce a new personality inventory based on Cloninger's Psychobiological model of personality to assess adolescents from 14 to 18 years of age (the Belgrade Adolescent Personality Inventory - BAPI), which bridges the gap between personality assessment in children and adults. The BAPI is a 46-item Likert scale inventory derived from previous studies using the TCI and JTCI on the Serbian sample. The psychometric properties of the BAPI were tested on the sample of 535 secondary school students in Serbia, aged 15 to 16. In order to assess the fit of the model, the Confirmatory factor analysis (CFA) was performed. The differences between sexes were analysed by MANOVA, while the Latent class analysis (LCA) was applied in order to identify different adaptation profiles among adolescents. The BAPI scales had a satisfactory internal consistency $(.66-.80$.) considering the small number of items (5-6) in each scale. The confirmatory factor analysis (CFA) generally supported the main dimensions of temperament and character, as postulated by Cloninger. The only exception was Novelty Seeking, which best fitted a two-factor solution, Explorative curiosity and Impulsivity, separating the "good" (curious, inquisitive, creative) and "bad" (impulsive, impatient, disorderly) facets of this trait. Such polarity of Novelty Seeking could be specific for personality development and behaviour disorders in adolescence. The LCA differentiated the personality profiles of well-adapted adolescents from those at risk for maladaptation that manifested low character
\end{abstract}

1 Rad je nastao u okviru naučno-istrazivačkog projekta Temperament i struktura poremećaja ličnosti (evidencioni broj: 175013), koji finansira Ministarstvo prosvete, nauke i tehnološkog razvoja Republike Srbije.

2 tamdzam@eunet.rs

3 Independent Consultant 
traits, lack of Persistence and high Novelty seeking Impulsivity subscale. The results support the construct validity of the BAPI and thus provide the basis for its practical application in personality assessment of adolescents and contribute to the theoretical understanding of personality structure and the risk of psychopathology in adolescence.

Keywords: temperament, character, adolescence, personality development and structure

\section{Introduction}

Since its introduction in the 1990s, the Psychobiological model of temperament and character (Cloninger, Svrakic, \& Przybeck, 1993; Cloninger, Przybeck, Svrakic, \& Wetzel, 1994), also known as the Seven Factor Model of personality, has undergone theoretical and structural modifications and is still being fine-tuned in empirical research. In this paper, we present one such step in the development of the TCI, specifically its new application in adolescents, labelled the Belgrade Adolescent Personality Inventory or ATCI.

The Seven Factor Model is a world-wide recognised psychobiological model of personality development and structure, described in detail in numerous articles, book chapters, and manuals (Svrakic \& Cloninger, 2005; Cloninger \& Svrakic, 2009). In brief, personality structure is conceptualised as consisting of two distinct but interacting components of temperament and character, each reflecting different forms of learning and memory and each providing unique psychophysiological and adaptive functions. Personality development is conceptualised as a self-organising multidimensional dynamical system created through Genes x Environment interaction, i.e., through reciprocal causality between biogenetic factors, experience, and adaptation. Such systems are defined as a complex adaptive system in biology.

The Seven Factor Model describes four temperament dimensions, which can be thought of as the "biological core" of personality, and three character dimensions, which can be thought of as the "adaptive interface" of personality. Each dimension is defined as a bipolar continuum of low and high expression, thereby capturing both normalcy and the extremes of behaviour traits.

Temperament traits develop early in life as behavioural derivatives of primary emotions (such as fear, aggression, sociability, and persistence), via associative learning (e.g., inhibition, activation, continuation, or persistence of behaviours) in response to specific environmental stimuli (e.g., danger, novelty, reward, and frustrating non-reward, respectively). The process creates stable percepts, affects, and memories through synaptic plasticity, manifested as temperament traits of Novelty Seeking (NS), Harm Avoidance (HA), Reward Dependence (RD) and Persistence (P) (Cloninger \& Svrakic, 2009; Svrakic, Draganic, Hill, Bayon, Przybeck, \& Cloninger, 2002). 
In comparison to temperament, character develops later in life, via conceptual and insight learning, influenced by social norms and experiencebased formation of adaptive personality features within the given social context (Svrakic \& Cloninger, 2010). In contrast to relatively stable temperament traits, character traits change (i.e., mature) with time, reflecting lifelong neural and behavioural plasticity to the rising intellectual capacity and socio-cultural influences. The developing character traits optimise adaptation of emotional temperament traits to the environment by reducing discrepancies between one's emotional needs and norm favouring social pressures (Svrakic, Svrakic, \& Cloninger, 1996). With advanced personal maturity and socialisation, character traits eventually also become stable characteristics of an individual (Svrakic \& Cloninger, 2010). The TCI character traits of Self-directedness (SD), Cooperativeness (CO) and Self-transcendent (ST) are described elsewhere (Cloninger et al., 1993).

In summary, character and temperament are etiologically related (either share the same biogenetic roots but develop via independent learning processes, or character develops from temperament via "socialisation" of temperament traits), developmentally related (final character outcomes are influenced by antecedent temperament traits) and functionally related (through bidirectional interaction, mature internalised concepts regulated by character modify the significance and the salience of sensory percepts and affects regulated by temperament and vice versa).

The Temperament and Character Inventory (TCI) has been developed to assess the above traits in clinical work and research. As a psychometric operationalisation of the seven-factor model of temperament and character (Cloninger et al., 1994 Cloninger et al., 2009) the TCI provides the basis for the empirical testing of the model's theoretical postulates. Research has generally supported the seven-factor model in clinical and non-clinical samples and in cross-cultural normative studies worldwide (Cloninger et al., 1994 Cloninger \& Svrakic, 2009). Over the years, there has been a growing interest to expand the use of the TCI in younger populations, both to address the need to assess personality in children, and to gain insight into personality development and structure during childhood and adolescence. To assess personality in children, the JTCI was developed (Luby, Svrakic, McCallum, Przybeck, \& Cloninger, 1999) and validated in numerous studies of children aged 9 to 13. The JTCI contains fewer items than the adult form (108 vs. 240 respectively). This reduction in the number of items was needed to ensure that children stay focused during the testing, adding to the validity of the results, but sacrificing some psychometric aspects of the inventory, its internal consistency in particular (Dukanac \& Džamonja Ignjatović, 2008). Adult TCI has been used in older adolescents with varying degrees of success (Dukanac, Džamonja Ignjatović, \& Peruničić, 2010). 


\subsection{The development of the BAPI: A novel application of the TCI in adolescents}

Our work in the development of the BAPI progressed as a step-wise process. We first attempted to assess personality of 14-17 year old adolescents by using a slightly adapted version of the JTCI (Dukanac \& Džamonja Ignjatović, 2008). In the later research minor linguistic and conceptual modifications were introduced to make the JTCI more appropriate for adolescents (Dukanac et al., 2010). In the sample of Serbian adolescents, the internal consistency of the modified JTCI scales ranged from .53 to .73 , which was not impressive but better in comparison to the same JTCI scales in Serbian children. Others have also noticed (Urgesi, Romanòa, Fornasaria, Brambilla, \& Fabbro, 2012) that psychometric performance of self-report personality tests improves with age, most likely reflecting the increasing ability for self-observation. Such suboptimal performance of the slightly modified JTCI in Serbian adolescents, initiated our work on the BAPI.

We first performed qualitative, i.e., cultural, contextual, and semantic, revisions of several JTCI items to make them more reflective of relevant life experiences and particular behaviours in adolescence. To match the newest revision of the TCI-R, the True/False format was changed into the 5-point Likert scale format. The above work led to the formulation of 80 items specifically "designed" for adolescents (Dukanac, Džamonja Ignjatović, \& Milanović, 2011). In a pilot research on the sample of 120 adolescents, in spite of the shortening of the scales, their internal consistency was satisfactory, with Cronbach's a ranging between .66 and .79, except for SD and CO, which had a low internal consistency.

To further improve the content and the reliability of the scales, especially of SD and $\mathrm{CO}$, two focus groups with adolescents were organised. Having been provided with a general descriptive summary of the main TCI scales, the participants were asked to identify an individual they knew well who exemplified each of the trait summaries. The participants were then asked to describe the corresponding behaviours of the identified exemplar individuals. Thematic analysis of the descriptions led to the identification of the behaviours specific of a dimension in Serbian culture, and these were then used to further adapt the TCI items for application in Serbia. A total of 84 items (12 items per trait) formulated this way was used in the exploratory factor analysis (EFA) in order to identify the most representative items for each domain. The EFA was performed for each scale separately on the convenience sample of 100 adolescents attending the grammar school in Zemun. The Novelty Seeking items loaded on two factors, Impulsivity (NS Im) and Exploratory curiosity (NS Ec). Although these two NS subfactors were inter-correlated, suggesting their close conceptual relatedness, 
each had a differential pattern of correlations with other TCI dimensions. Exploratory curiosity (or Novelty seeking in the narrow sense of the term) was quite independent from other TCI traits. In contrast, Impulsivity was negatively correlated with $\mathrm{P}, \mathrm{SD}$ and $\mathrm{CO}$ and positively correlated with $\mathrm{HA}$. As impulsivity carries a special importance for the assessment of adolescents (who are usually described as hasty, irritable, non-persistent, prone to risky behaviour, etc.), we devoted special attention to the items relevant to impulsivity in order to operationalise it precisely during the finalisation of the BAPI.

The EFA led to the formulation of the BAPI which retained 46 items. Specifically, each BAPI temperament and character scale consists of 6 items $(6 \times 6=36)$ except for NS, where 10 items $(36+10=46)$ were kept in order to closely examine its structure in this age group (see below).

\subsection{Goals}

This study had two main goals. First, we wanted to test whether the Sevenfactor model of temperament and character fits the empirical data from the BAPI in the general adolescent population. As noted, we also tested whether the NS scale fits the data in adolescents better as a single scale or as two facets, i.e., Impulsivity and Exploratory curiosity. The separation or disintegration of these two NS facets could be a unique developmental feature of personality structure in adolescence, with special importance for assessment risk for the development of personality disorder at this age. Second, based on the theoretical assumptions of the Seven Factor Model on maladaptation, we investigated whether different groups of adolescence could be identified by the ATCI and what is the relationship between the characteristics of those groups and theoretical characteristics of well-adapted adolescents and adolescents that are at risk of developing a personality disorder in our nonclinical sample.

Our specific objectives were:

1. To compare the goodness of fit between 1-facet NS and 2-facet NS temperament models;

2. To test the internal structure of the best fitting temperament and character model;

3. To test measurement invariance of the BAPI across gender groups and examine gender differences on temperament and character dimensions;

4. To check the internal consistency (reliability) of the scales;

5. To test the potential of the BAPI to differentiate functional from dysfunctional behaviour among adolescents. 


\section{Method}

\subsection{Participants}

The sample consisted of 535 secondary school students between 15 and 16 years of age, recruited in three Serbian cities during 2012: Zaječar, Novi Sad and Belgrade. There were 225 (42.1\%) male and 310 (57.9\%) female adolescents. The study was conducted as a part of psychology classes. Participation was voluntary and anonymous.

\subsection{Measures}

The BAPI has been developed to study temperament and character traits in adolescents between 14 and 18 years of age. The questionnaire consists of 46 items grouped in 7 scales. Four temperament scales include NS, HA, RD, and P, and three character scales are SD, CO, and ST. Each scale consists of 6 items, except NS which consists of 10 items, 5 for Exploratory curiosity and 5 for Impulsivity. The ACTI is scored on a 5-point Likert-type scale.

Although the number of items in the BAPI has been significantly reduced in comparison to the original JTCI, the content of items was maximally representative for the postulated constructs in the JTCI and adult TCI. We were aware that our emphasis was on the representativeness of items, rather than on their homogeneity, and could result in lower reliability of the scales. It was very important to make a short inventory that would be suitable for adolescents to complete items carefully and provide reliable answers.

\subsection{Data analysis}

In order to assess the fit of the model and to compare 1- and 2-facet models of NS, the confirmatory factor analysis (CFA) was performed with AMOS 22. The covariance matrix was analysed with Maximum likelihood (ML) estimation procedure, with the correction for the chi-square and bootstrap intervals. Evaluation of the appropriateness of model fit was focused on fit indices, instead of the $\chi^{2}$ test which is oversensitive to minor deviations from the model (Brown, 2006). The following fit indices were selected: Standardised Root Mean Square Residual (SRMR) and Root Mean Square Error of Approximation (RMSEA) (Steiger, 1990) as absolute fit indices, Comparative fit index (CFI) (Bentler, 1990) and Tucker-Lewis index (TLI) (Tucker \& Lewis,1973) as incremental fit index, and Akaike Information Criterion AIC (Akaike, 1987) as a criterion for model selection. Although the RMSEA and TLI generally fall into the category of absolute/incremental fit indices respectively, the RMSE and TLI also incorporate penalty function for poor model parsimony (Brown, 2006). 
As fit indices are influenced by the parameters not related to the misspecification in the model, the cutoff values for model fit indices cannot be interpreted independently of the parameters such as the size of unique variances, complexity of model, type of model and size of sample (Brown, MacCallum, Kim, 2002; Yuan, 2005; Fan \& Sivo, 2007; Saris, Satorra, \& van der Veld 2009; Heene, Hibert, Draxler, Ziegler, \& Bühne, 2011). In other words, there are no grounds for establishing fit index cutoff criteria that would be generally applicable. In a situation with a larger number of observed variables, the correlated factor model, the medium size of sample and medium values of factor loadings with an average value of $.54(\mathrm{SD}=.09)$ for temperament and $.53(\mathrm{SD}=.09)$ for character domain, both the RMSEA and CFI tend to decrease, with the CFI more biased, so the statistical power of both indices to detect misfit is altered in respect to the recommended values by $\mathrm{Hu}$ and Bentler (1999), Kenny and McCoach (2003) and Marsh, Hau and Wen (1999). On the basis of the study of Heene et al., (2011), we can expect that if our model is misspecified, the RMSEA could be .088, and CFI could be between .691 and .698. These mean that the recommended CFI value of .90 is too conservative as a cutoff value of the acceptable model fit, so smaller values of the CFI could also be an indicator of adequate fit and for the RMSEA, value of .08, proposed by Browne and Cudeck (1993) is too liberal as a cutoff value for reasonable fit, so we have adopted the value of .06 as a minimum for reasonable fit. The value of the SRMR $<.08$ was treated as acceptable. Since there is no generally accepted cutoff value for the AIC criterion, lower values are interpreted to indicate a better model fit. The $\chi^{2} / \mathrm{df}$ value less than 3.0 was acceptable (Briggs \& Cheek, 1986). The measurement invariance between sexes was tested with multiple-group CFA and reported as recommended by Brown (2006).

Separate CFAs were performed for temperament and character domains as recommended by Cloninger (2008). Two models for temperament domain were examined: the 1-factor model that postulates that there is only one factor - Novelty Seeking, with 10 items, and the 2-factor model that postulates the existence of two different factors: Exploratory curiosity with 5 items and Impulsivity with 5 items. The differences between sexes were analysed by multivariate analysis of variance (MANOVA), followed by discriminant analysis. The latent class analysis (LCA) was applied in order to examine if and how many groups could be identified among adolescents. The LCA is a statistical method commonly used to test for the existence of the discrete groups of cases with similar characteristics based on multivariate data. These homogenous subgroups form the categories of a categorical latent variable. The LCA has no requirements for the distribution of data and also provides objective indices of class classification accuracy and fit indices, offering robust statistical tests for determining the optimal number of classes (Nylund, Asparouhov, \& Muthén, 2007). Model selection was based on the Bayesian information criterion (BIC), 
while Lo-Mendell-Rubin's adjusted likelihood ratio test (LRT) and the measure of entropy were used to assess accuracy of classification.

\section{Results}

Data entry and the computation of descriptive statistics and Cronbach's a coefficients were performed with SPSS 19 software. Missing data were random and were imputed by multiple imputation method.

Although Mardia's coefficient was above the critical value for both sets of temperament and character items, only the items $\mathrm{CO} 1$ and P1 did not reach the usual endorsement criterion threshold (Streiner \& Norman, 2008). The arithmetic mean of skewness and kurtosis (in absolute value) for the items of temperament was $.53(\mathrm{SD}=.47)$ and $.73(\mathrm{SD}=.89)$ and for character items $.68(\mathrm{SD}=.49)$ and $1.10(\mathrm{SD}=1.17)$ respectively. Since maximum likelihood estimation performs well with mild nonnormal data without missing data and on the sample of this size (Streiner \& Norman, 2008; Savalei, 2008), there was no need to use the asymptotically distribution-free (ADF) method of estimation.

\subsection{Internal structure}

Goodness-of-fit statistics for each model are displayed in Table 1. As for the two models of temperament, based on the AIC, it can be seen that the 2 -factor NS model better fits the data than the 1-factor NS. The fit for both 2 -factor NS temperament model and character model was good based on absolute fit indices, while the character model also had generally acceptable values of incremental fit indices, for the 2-factor NS temperament model those indices were slightly lower than .90 . Based on the discussion of the generalisability of the cut-off values of fit indices and the fact that the CFI is biased under the conditions previously specified, we have accepted this fit as reasonable. Based on the goodness-of-fit indices it can be concluded that the 2 -factor NS model and the character model provide good fit to the data.

Table 1. The summary of the CFA goodness-of-fit statistics for the 1-factor NS temperament, 2-factor NS temperament and character model

\begin{tabular}{lccccccccc}
\hline \multicolumn{1}{c}{ Models } & $\chi^{2}$ & $d f$ & $\chi^{2} / d f$ & RMSEA (90\% CI) & SRMR & TLI & CFI & AIC \\
\hline $\begin{array}{l}\text { Temperament } \\
\text { 1-factor NS }\end{array}$ & $1021.62^{* *}$ & 342 & 2.99 & $\begin{array}{c}0.061 \\
(.057-.065)\end{array}$ & 0.081 & 0.76 & 0.78 & 1149.62 \\
$\begin{array}{l}\text { Temperament } \\
\text { 2-factor NS }\end{array}$ & $751.24^{* *}$ & 338 & 2.22 & $\begin{array}{c}0.048 \\
(.043-.052)\end{array}$ & 0.061 & 0.85 & 0.87 & 887.24 \\
\hline Character & $233.15^{* *}$ & 131 & 1.78 & $\begin{array}{c}0.038 \\
(.032-.042)\end{array}$ & 0.044 & 0.91 & 0.93 & 349.15 \\
\hline
\end{tabular}

${ }^{\star *} \mathrm{p}<.001$ 
All factor loadings for the temperament and character domain were significant $(\mathrm{p}<.01)$ and salient, with the range from .41 to .70 for the temperament domain, and from .30 to .70 for the character domain.

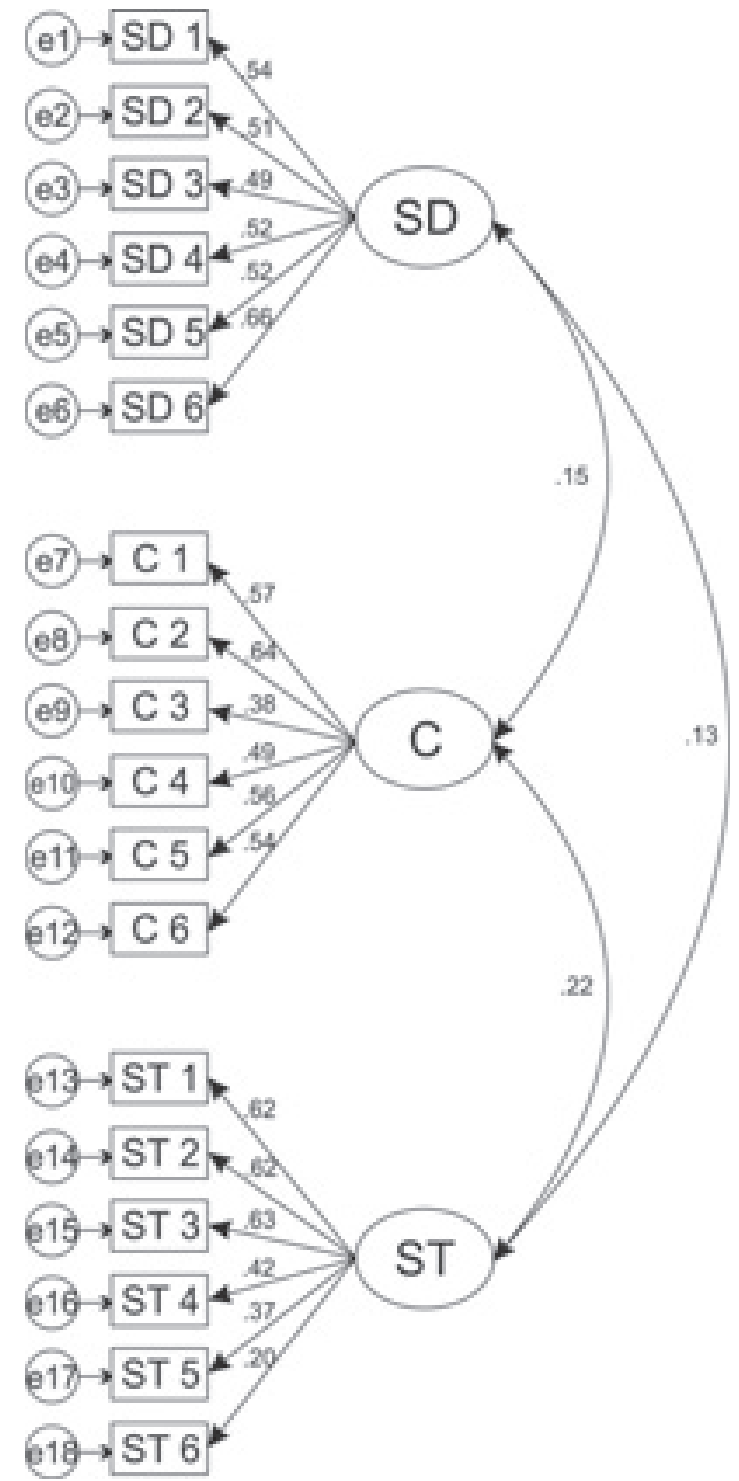

Picture 1. Factor loadings and factor correlations for the 2-factor NS temperament model 


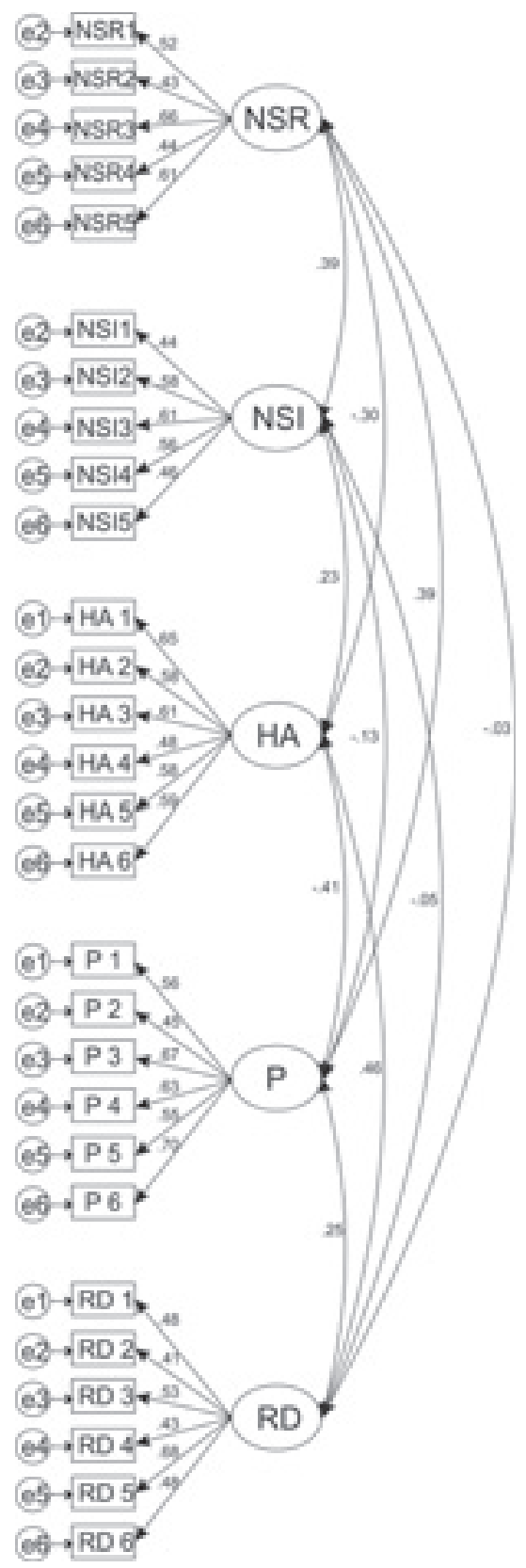

Picture 2. Standardised factor loadings and factor correlations for the character model

Table 2 shows intercorrelations among the BAPI temperament and character subscales. In accordance with previous work (Dukanac \& Džamonja 
Ignjatović, 2008; Urgesi et al, 2012), specific temperament and character traits were highly correlated, e.g., HA and SD (-.56), RD and CO (.67), and P with both character dimensions, SD and C (.57; .43, respectively).

Table 2. Intercorrelations of temperament and character BAPI subscales

\begin{tabular}{lccc}
\hline \multicolumn{1}{c}{ Subscale } & SD & CO & ST \\
\hline NS Im & $-.09^{\star}$ & -.06 & .05 \\
NS Ec & $.35^{\star *}$ & $.13^{\star *}$ & .01 \\
HA & $-.56^{\star *}$ & $.17^{\star *}$ & $.13^{\star *}$ \\
RD & -.04 & $.67^{\star *}$ & $.12^{\star *}$ \\
$\mathrm{P}$ & $.57^{\star *}$ & $.43^{\star *}$ & $.03^{\star *}$ \\
${ }^{* *} \mathrm{p}<.001 ;{ }^{*} \mathrm{p}<.005$ & & &
\end{tabular}

Measurement invariance of the BAPI between groups defined by sex was tested both for the temperament and character domain. As shown in Table 3 factor structure (configural invariance/equal form), factor loadings (metric invariance/equal factor loadings), response tendency (scalar invariance /equal indicator intercepts) and indicator error variance invariance were supported for the character domain. The results are not so clear for the temperament domain. Factor structure (configural invariance/equal form) and factor loadings (metric invariance/equal factor loadings) invariance for the model of temperament should be accepted with caution based on the determined criteria, but the support is less clear for the response tendency (scalar invariance/equal indicator intercepts) and indicator error variance invariance for this model. While absolute fit indices are acceptable to good, incremental fit indices are low, although the CFI is much higher than expected if the model is misspecified. This can call into question the comparability of scores for boys and girls for the temperament domain.

Table 3. Test of measurement invariance across sex groups for the temperament and character model

\begin{tabular}{|c|c|c|c|c|c|c|c|c|c|}
\hline Models & $x^{2}$ & $d f$ & $\chi^{2} / d f$ & $\chi_{\text {diff }}^{2}$ & $\Delta d f$ & RMSEA (90\% CI) & SRMR & TLI & CFI \\
\hline \multicolumn{10}{|l|}{ Temperament } \\
\hline Configural invariance & 1135.85 & 676 & 1.68 & & & $.036(.032-.039)$ & .076 & 0.83 & 0.85 \\
\hline Metric invariance & 1175.01 & 699 & 1.68 & 39.16 & 23 & $.036(.032-.039)$ & .079 & 0.83 & 0.85 \\
\hline Scalar invariance & 1310.53 & 727 & 1.80 & 135.53 & 28 & $.039(.036-.042)$ & .079 & 0.80 & 0.81 \\
\hline $\begin{array}{l}\text { Error variance } \\
\text { invariance }\end{array}$ & 1391.38 & 770 & 1.81 & 80.85 & 43 & $039(.036-.042)$ & .080 & 0.80 & 0.80 \\
\hline \multicolumn{10}{|l|}{ Character } \\
\hline Configural invariance & 387.38 & 264 & 1.47 & & & $.030(.023-.036)$ & .072 & 0.89 & 0.91 \\
\hline Metric invariance & 408.28 & 279 & 1.46 & 20.9 & 15 & $.030(.023-.036)$ & .074 & 0.89 & 0.90 \\
\hline Scalar invariance & 475.55 & 297 & 1.60 & 67.27 & 18 & $.034(.028-.040)$ & .074 & 0.86 & 0.87 \\
\hline $\begin{array}{l}\text { Error variance } \\
\text { invariance }\end{array}$ & 529.814 & 321 & 1.65 & 54.264 & 24 & $.034(.030-.041)$ & .079 & 0.85 & 0.84 \\
\hline
\end{tabular}




\subsection{Means, SD and internal consistency reliability of the BAPI}

Table 4 displays mean, standard deviation, skewness, kurtosis and Cronbah's a coefficients of internal consistency for all subscales. It can be seen that most scales have acceptable reliability, except NS scales and CO. Although some of the coefficients are below .70, this level of reliability is not so bad if we have in mind that subscales are very short and cover the whole concepts of personality dimensions.

Table 4. Descriptive statistics

for the subscales of temperament and character

\begin{tabular}{lcccccc}
\hline \multicolumn{1}{c}{ Subscale } & Mean & SD & Skewness & Kurtosis & $\begin{array}{c}\text { Number } \\
\text { of items }\end{array}$ & $\alpha$ \\
\hline Novelty seeking - Impulsivity & 16.79 & 4.03 & -0.14 & -0.33 & 5 & .66 \\
Novelty seeking - Research curiosity & 18.58 & 3.65 & -0.51 & 0.31 & 5 & .67 \\
Harm avoidance & 18.72 & 5.22 & -0.17 & -0.45 & 6 & .76 \\
Reward dependence & 21.55 & 4.28 & -0.45 & 0.37 & 6 & .70 \\
Persistence & 23.81 & 4.21 & -0.89 & 0.99 & 6 & .78 \\
Self-Directedness & 21.82 & 4.56 & -0.48 & 0.14 & 6 & .71 \\
Cooperation & 24.12 & 3.70 & -0.84 & 0.86 & 6 & .69 \\
Self-Transcendence & 19.84 & 5.55 & -0.40 & -0.32 & 6 & .80 \\
\hline
\end{tabular}

\subsection{Relation to sex}

The results of the multivariate analysis of variance (MANOVA) indicate that there are significant and relevant differences in the temperament domain between sexes, Wilks' $\Lambda$ equals .91, $F(5,529)=10.09, \mathrm{p}>.001$, while there are statistically significant, but not relevant (explain less than $5 \%$ of variance) differences between the sexes for the character domain, Wilks' $\Lambda$ equalling .98. $F(3,531)=3.29, p<.05$. Nevertheless, we have to be cautious in the interpretation of this difference since scalar invariance was not strongly supported for the temperament domain.

\subsection{Latent class analysis}

One of the goals was to test how many different and homogenous groups the BAPI can discriminate among the "normal" population of adolescents, as well as whether the differences can be interpreted in terms of successful and unsuccessful adaptation. The latent class analysis was employed on the scores on BAPI scales in order to test for the existence of homogenous groups. Because of parsimony three models were tested: with two, three and four classes. For the two-class solution entropy was .83, and the LoMendell-Rubin's adjusted likelihood ratio test was nonsignificant, which 
indicates that other solutions need not be considered. This is also confirmed by the decrease in entropy with the increase in the number of classes: for the three-class solution entropy was .75 and for the four-class solution .71. The characteristics of classes are given in Table 5.

Table 5. Descriptive statistics for latent class groups on standardised scores of temperament and character scales

\begin{tabular}{ccccc}
\hline & \multicolumn{2}{c}{$\begin{array}{c}\text { Class 1 - Functional } \\
(N=439)\end{array}$} & \multicolumn{2}{c}{ Class 2 - Dysfunctional } \\
& N $N=96)$ \\
\cline { 2 - 5 } & $\mathrm{M}$ & $\mathrm{SD}$ & $\mathrm{M}$ & $\mathrm{SD}$ \\
\hline NS Im & -.05 & .99 & .25 & 1.02 \\
NS Ec & .16 & .89 & -.72 & 1.16 \\
HA & -.13 & .96 & .57 & .97 \\
RD & .10 & .98 & -.44 & .99 \\
P & .34 & .67 & -1.53 & .79 \\
SD & .26 & .80 & -1.20 & .93 \\
CO & .17 & .89 & -.77 & 1.12 \\
ST & .02 & .99 & -.10 & 1.03 \\
\hline
\end{tabular}

Psycho-socially well-adapted adolescents are characterised by lower scores on HA and impulsivity (NS Im) and higher scores on explorative curiosity (NS Ec) on the temperament scales. Larger differences can be noticed through higher scores on $\mathrm{P}$ and $\mathrm{SD}$ and $\mathrm{CO}$ on the character scales. Therefore, the profile of adolescents who are under risk of developing certain personality pathology represents a "mirror image" of the successfully adapted adolescents. Their characteristics are increased impulsivity NS Im, but decreased curiosity NS Ec (this is also an important reason why these scales should be measured separately), increased $\mathrm{HA}$, especially low $\mathrm{P}$ and a bit lower $\mathrm{RD}$, as well as a significant decrease in the character scales of SD and $\mathrm{CO}$ (Picture 3.). There are no relations between sex and membership of classes, $\chi^{2}(1, \mathrm{~N}=535)=.66, p=.43$.

\section{LCA}

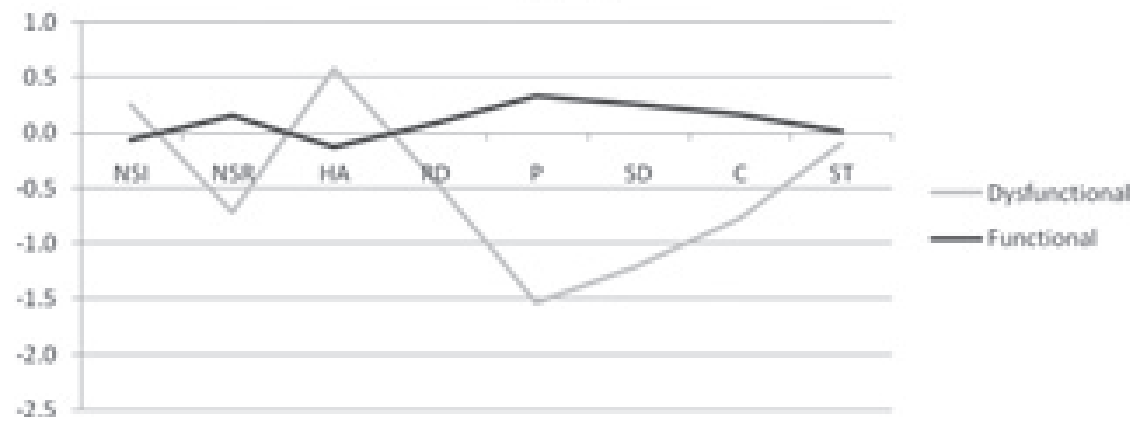

Picture 3. Latent classes profiles on standardised scores of temperament and character subscales 


\section{Discussion}

Personality tests designed for children or adults are not always reliable when applied unmodified to adolescents (Luby et al, 1999; Dukanac \& Džamonja Ignjatović, 2010). The BPI bridges the gap between personality assessment in children (JTCI) and adults (TCI). Our intention was to develop a specific test relevant to adolescents that can serve as a sound basis for empirical testing of theories about personality structure and development at this age. All this could potentially lead to important diagnostic, treatment, and nosologic implications.

The BAPI provides a valid and moderately reliable assessment of basic temperament and character dimensions in adolescents as postulated in Cloninger's theory of personality (Cloninger et al, 1993; Cloninger et al, 1994). Based on the feedback from interactive focus groups and a number of psychometric analyses, the 46-item BAPI was developed to achieve an adequate number, length, and content of items to make them relevant for adolescents.

The CFA results have shown that the proposed structure of the BAPI fits the empirical data well both at the level of temperament and at the level of character. However, based on the CFA, and using the AIC as the criterion (see the method section), it appears that a two-facet NS (consisting of Exploratory curiosity and Impulsivity) better fits personality structure in adolescents, which may have important theoretical and diagnostic ramifications. In fact, the polarity of Novelty Seeking for personality development and behaviour disorders in adolescence, as the phenomenon, could be expected in children and adults as well. Those findings are similar to Dickman's functional and dysfunctional impulsivity (Dickman, 1990).

Other research has also suggested that impulsivity may be a heterogeneous construct, lumping together the difficulties in the inhibition of behavioural responses and a decreased capacity for delaying one's reactions, excitement seeking, risk taking, courage, adventurism, boredom intolerance, motor disinhibition, inability of planning ahead and strong preference of immediate rewards, among others (Flory, Harvey, Mitropoulou, New, Silverman, Siever, \& Manuck, 2006; Barratt, 1985, 1994; Depue \& Collins, 1999; Evenden, 1999; Moeller Moeller, Barratt, Dougherty, Schmitz, \& Swanet., 2001; Monterosso and Ainslie, 1999; Newman \& Wallace 1993). Based on factor analysis of items from various personality inventories, Flory et al. have identified three impulsivity factors: Lack of planning, Disinhibited behaviours and Excitement seeking (Flory et al., 2006).

Our data for adolescents indicate that Impulsivity has a weak negative correlation with $\mathrm{P}(-.13)$ and positive correlation with HA (.23). In other words, "adolescent impulsivity" appears to be reflecting emotionally unstable adolescents. Exploratory curiosity refers to one's interest in pursuing new 
events and had the exact opposite direction of the correlations with the same scales, P (.39) and HA (-.30).

Configural and metric invariance of the model indicate that factor structure of the BAPI is invariant for adolescents of both sexes. A scalar invariance for the character has been supported, but one has to be careful when making conclusions about the differences between the sexes in terms of temperament. In other words, one cannot absolutely claim that the same score on the scales of temperament for men and women corresponds to the same intensity of the latent dimension. There are no gender differences in character dimensions compared to average scores, but in terms of temperament, girls have higher scores for HA, RD and Impulsivity. The difference is small, and in accordance to the above-stated, we cannot unilaterally assign this to the difference in latent dimension.

Reliability of the BAPI is solid, indicating that the small number of items does not significantly decrease scale reliability. On the other hand, the validity of the responses of adolescents, who do not lose motivation and patience during the short time of testing, appears to increase. Due to the small number of items, the BAPI also provides a quick and easy assessment in clinical practice and empirical research. Finally, linguistic and semantic adaptation of items to make them familiar to adolescents appears to improve the subject's understanding of the test and decrease their resistance to it.

The results suggest the ability of the BAPI to differentiate the specific personality profiles of adapted and maladapted adolescents. The LCA has clearly separated these two groups. According to the theoretical assumptions and previous empirical findings obtained with the TCI for adults in clinical samples, the BAPI isolated the group of adolescents who are immature or at risk for personality pathology and who manifest decreased scores on character dimensions of SD and CO, while ST seems irrelevant for these intragroup differences at this age. The differences in temperament are not as impressive although it appears that high impulsivity (NS Im) and high HA tend to interfere with successful adaptation. The most impressive differences between the two groups, adapted and maladapted, were observed in Persistence (high in adapted, low in maladapted). This can be due to the fact that the character itself at the age of 15 or 16 is still undergoing finalisation. Thus, Persistence may be the dimension that serves as the "link" between temperament and character and may be even developed on this basis. Persistence may be understood as a "vector" reflecting balanced, non-extreme (vs. extreme and destabilising) temperament dimensions and as such could represent a pivotal factor in character outcomes and (mal)adaptation. This result has both theoretical implications for the pathogenesis of personality disorders in adolescence and significant practical applications in diagnosing the early risks of the aberrant development. 
The observed high correlations between temperament and character traits in adolescence could reflect the etiogenesis of character from specific temperament antecedents. In that sense, high scores on HA that contribute to proneness towards negative feelings (i.e., anxiety, depression, fatigue) can interfere with the development of SD (i.e., resourcefulness, purposefulness, self-acceptance, assertiveness, etc.), while Exploratory curiosity (NS Ec) could facilitate SD. Also, RD (i.e., sensitivity to rewards, emotional attachment, warmth, etc.) can positively influence the development of $\mathrm{CO}$, while high $\mathrm{P}$ could significantly facilitate development of stable character traits of SD and CO.

Future studies of adolescents need to address the structure of NS (exploratory curiosity and impulsivity) at other ages, as well as in a clinical sample of adolescents.

One might speculate that the observed high correlations between temperament and character traits in adolescents (in fact higher than those observed in children or adults) clearly point out to the etiological connection between the temperament and character, where character traits arise from temperament in a complex interaction of environmental factors and interactive effects of personality dimensions themselves. Especially interesting is the status of Persistence, which according to our results appears to significantly facilitate the development of stable character traits of SD and CO.

Since the positioning of Persistence within the model has remained somewhat unclear due to its later derivation from Reward Dependence, Persistence serves as a possible developmental link between temperament and character. These findings also require further studying.

Finally, our results offer suggestive evidence for differentiating adolescents at risk for personality pathology, but further study is indicated in clinical samples.

In addition to providing a sound and specific basis for empirical testing of Cloninger's theoretical postulates in adolescents, the relatively short, linguistically and conceptually adapted BAPI questionnaire is convenient to be used for a quick assessment or screening of young persons at risk in various areas - in education systems, social work setting, or clinical practice.

\section{References:}

Akaike H. (1987). Factor analysis and AIC. Psychometrika, 52, 317-22.

Barratt, E. S. (1985). Impulsiveness subtraits: Arousal and information processing. In: J. T. Spence, C. E. Izard (Ed.), Motivation, Emotion, and Personality. Amsterdam: Elsevier/North-Holland.

Barratt, E. S. (1994). Impulsiveness and aggression. In: J. Monahan, H. J. Steadman, (Ed.), Violence and mental disorder. Chicago: University of Chicago Press.

Bentler P.M. (1990). Comparative fit indexes in structural models. Psychological Bulletin 107, 238-46. 
Briggs, S. R., Cheek, J. M. (1986) The role of factor analysis in the development and evaluation of personality scales. Journal of Personality, 54, 106-48.

Browne, M. W., Cudek, R. (1993). Alternate ways of assessing model fit. In: K. A. Bollen, J. S. Long (Ed.), Testing structural equation models. Newbury Park, CA: Sage.

Brown, W. M., MacCallum, C. R., Kim, C. T. (2002). When Fit Indices and Residuals Are Incompatible. Psychological Methods, 7, 403-421.

Brown, T. A. (2006). Confirmatory Factor Analysis for Applied Research. New York: Guilford Press.

Cloninger, C. R., Svrakic, D. M., Przybeck, T. R. (1993): A psychobiological model of temperament and character. Archives of General Psychiatry, 50, 975-90.

Cloninger, C.R., Przybeck, T. R., Svrakic, D. M., Wetzel, R. D. (1994). Manual of Temperament and Character Inventory (TCI): A Guide to its Development and Use. St. Louis, MO: Washington University.

Cloninger, C. R. (2008). The Psychobiological Theory of Temperament and Character: Comment on Farmer and Goldberg. Psychological Assessment, 20, 292-299.

Cloninger, C. R., Svrakic, D. (2009). Personality Disorders. In: B. J. Sadock, V. Sadock, (Ed.) Kaplan and Sadock's Comprehensive Textbook of Psychiatry. 9th ed. Williams \& Wilkins, NY. 2197-2240.

Depue, R. A., Collins, P. F. (1999). Neurobiology of the structure of personality: Dopamine, facilitation of incentive motivation, and extraversion. Behavioral and Brain Sciences, 22, 491-569.

Dickman, S. J. (1990). Functional and dysfunctional impulsivity: personality and cognitive correlates. Journal of Personality and Social Psychology, 58, 95-102.

Dukanac, V., Džamonja Ignjatović, T., Peruničić, I. (2010). Primena upitnika u proceni socijalne zrelosti adolescenata. In: V. Curčić, V. Išpanović Radojković, (Ed.) DEAPS, Zlatibor. Knjiga apstrakata. DEAPS, Beograd.

Dukanac, V., Džamonja Ignjatović, T. (2008). Kros-kulturalna komparacija dece uzrasta 11-13 godina na junior-TCI inventaru temperamenta i karaktera. Psihologija, 41,177-194.

Dukanac, V., Džamonja Ignjatović, T., Milanović, M. (2011). Konstrukcija i psihometrijska provera upitnika temperamenta i karaktera za adolescente ATCI-80. Engrami, 33, 5-17.

Evenden, J. L. (1999). Varieties of impulsivity. Psychopharmacology, 146, 348-361.

Fan, X., Sivo, A. S. (2007). Sensitivity of Fit Indices to Model Misspecification and Model Types. Multivariate Behavioral Research, 42, 509-529.

Flory, J. D., Harvey, P. D., Mitropoulou, V., New, A. S., Silverman, J. M., Siever, L. J., Manuck, S. B. (2006). Dispositional impulsivity in normal and abnormal samples. Journal of Psychiatric Research, 40, 438 - 447.

Heene, M., Hibert, S., Draxler, C., Ziegler, M., Bühner, M. (2011). Masking misfit in confirmatory factor analysis by increasing unique variances: a cautionary note on the usefulness of cutoff values of fit indices. Psychological Method, 16, 319 - 336.

$\mathrm{Hu}, \mathrm{L}$. , Bentler, P. M. (1999). Cutoff criteria for fit indexes in covariance structure analysis: Conventional criteria versus new alternatives. Structural Equation Modeling, 6, 1-55. 
Kenny, A. D., McCoach, D. B. (2003). Effect of the Number of Variables on Measures of Fit in Structural Equation Modeling. Structural Equation Modeling, 10, 333-351.

Luby, J. L., Svrakic, D. M., McCallum, K., Przybeck, T. R., Cloninger, C. R. (1999). The Junior Temperament and Character Inventory: Preliminary validation of a child self-report measure. Psychological Reports,. 84,1127-1138.

Marsh, H. W., Hau, K-T., Wen, Z. (2004). In search of golden rules: comment on hypothesis-testing approaches to setting cutoff values for fit indexes and dangers in overgeneralizing Hu and Bentler's (1999) findings. Structural Equation Modeling, 11, 320-341.

Moeller, F. G., Barratt, E. S., Dougherty, D. M., Schmitz, J. M., Swan, A. C. (2001). Psychiatric aspects of impulsivity. American Journal of Psychiatry, 158, 1783-1793.

Monterosso, J., Ainslie, G. (1999). Beyond discounting: possible experimental models of impulse control. Psychopharmacology, 146, 339-347.

Newman, J. P., Wallace, J. F. (1993). Diverse pathways to deficient self-regulation: Implications for disinhibitory psychopathology in children. Clinical Psychology Review, 13, $699-720$.

Nylund, K. L., Asparouhov, T., \& Muthén, B. (2007). Deciding on the number of classes in latent class analysis and growth mixture modeling: A Monte Carlo simulation study. Structural Equation Modeling: A Multidisciplinary Journal, 14, 535-569

Savalei, V. (2008). Is the ML chi-square ever robust to nonnormality? A cautionary note with missing data. Structural Equation Modeling, 15, 1-22.

Saris, E. W., Satorra, A., van der Veld, M. W. (2009). Testing Structural Equation Models or Detection of Misspecifications? Structural Equation Modeling, 16, 561-582.

Steiger, J. H. (1990). Structural model evaluation and modification: an interval estimation approach. Multivariate Behavioral Research, 25, 173-80.

Streiner, D. L., Norman, G. R. (2008). Health measurement scales: a practical guide to their development and use. 4th ed, New York: Oxford University Press.

Svrakic, D. M., Draganic, S., Hill, K., Bayon, C., Przybeck, T. R., Cloninger, C. R. (2002). Temperament, Character, and Personality Disorders: Etiologic, Diagnostic, Treatment issues. Acta Psychiatrica Scandinavica, 106, 189-95.

Svrakic, D. M., Cloninger, R. C. (2010). Epigenetic perspective on behavior development, personality, and personality disorders. Psychiatria Danubina, 22,153-66.

Svrakic, N. M., Svrakic, D., Cloninger, C. R. (1996). A general quantitative theory of personality: fundamentals of a self-organizing psychobiological complex. Development and Psychopathology, 8, 247-272

Svrakic, D., Cloninger, C. R. (2005). Personality Disorders. In: B. J. Sadock, V. Sadock (Ed.) Kaplan and Sadock's Comprehensive Textbook of Psychiatry. 8th ed. Williams \& Wilkins, NY. 2063-2104.

Tucker, L. R., Lewis, C. (1973). A reliability coefficient for maximum likelihood factor analysis. Psychometrika, 38, 1-10.

Urgesi, C., Romanòa, M., Fornasaria, L., Brambilla, P., Fabbro, F. (2012). Investigating the development of temperament and character in school-aged children using a self-report measure. Comprehensive Psychiatry, 53, 875-883.

Yuan, K-H.(2005). Fit indices versus test statistics. Multivariate Behavioral Research, 40, 115-148. 


\section{Beogradski inventar za procenu ličnosti adolescenata kao most između procene ličnosti dece i odraslih}

\section{Džamonja Ignjatović Tamara}

Fakultet političkih nauka, Univerzitet u Beogradu

\section{Milanović Marko}

Beograd

\section{Dukanac Vesna}

Institut za mentalno zdravlje, Belgrade

S obzirom da postoji nedostatak namenski konstruisanih inventara za procenu i proučavanje ličnosti adolescenata koji su u uzrastu ključnom za završetak kako normalnog, tako i patološkog mentalnog razvoja, u radu je predstavljen novi inventar ličnosti zasnovan na Klonindžerovom Psihobiološkom modelu ličnosti. Beogradski Inventar Ličnosti Adolescenata (BILA) koristi se za procenu adolescenata uzrasta od 14 do 18 godina i trebalo bi da premosti jaz između procene ličnosti kod dece i odraslih. Upitnik obuhvata 46 stavki Likertovog tipa i nastao je na osnovu prethodnih istraživanja u kojima su korišćeni TCI i JTCI na uzorku naših ispitanika. Psihometrijske karakteristike upitnika ispitane su na uzorku od 535 srednjoškolaca iz Srbije, starosti od 15 do 16 godina. Kako bi se utvrdila adekvatnost modela, urađena je konfirmatorna faktorska analiza. U cilju analize polnih razlika korišćena je MANOVA, dok je analiza latentnih klasa primenjena kako bi se utvrdilo da li se mogu izdvojiti specifični profil ličnosti adolescenata iz uzorka iz opšte populacije. Skale upitnika pokazale su zadovoljavajuću internu konzistenciju (.66 - .80), posebno imajući u vidu mali broj stavki (5-6) u svakoj skali. Konfirmatorna faktorska analiza je načelno potvrdila glavne dimenzije temperamenta i karaktera onako kako ih je definisao Klonindžer. Jedini izuzetak je bio u slučaju Potrage za novinama, za koju je podesnije dvofaktorsko rešenje. Potragu za novinama čine Eksplorativna radoznalost i Impulsivnost koie razlikuju "dobre" (znatiželjan, radoznao, kreativan) i "loše" (impulsivan, nestrpljiv, haotičan) odlike ove dimenzije. Ovaj polaritet Potrage za novinama mogao bi da bude specifičan za razvoj ličnosti i poremećaja u ponašanju tokom adolescencije. Analizom latentnih klasa utvrđene su razlike između profila ličnosti dobro adaptiranih adolescenata i onih kod kojih postoji rizik za razvoj problema u ponašanju, a koji imaju nizak skor na crtama karaktera, niži stepen Perzistencije i povišenu Impulsivnost. Dobijeni rezultati potvrđuju konstrukt validnost BILA upitnika i što omogućava njegovu praktičnu primenu u proceni ličnosti adolescenata, pružajući doprinos teorijskom razumevanju strukture ličnosti i rizika od psihopatologije u adolescenciji.

Ključne reči: temperament, karakter, adolescencija, razvoj i struktura ličnosti. 